\title{
Irrigated agriculture and the environment in the Tarim River watershed: case study of the Shaya irrigation district in the Ugen River basin
}

\author{
T. Yamamoto, T. Nagasawa \& A. Jalaldin \\ Graduate School of Agriculture, Hokkaido University, Japan
}

\begin{abstract}
Irrigation in arid regions like the Tarim River watershed causes salinization and influences the regional environment. In this paper, problems between agricultural wateruse and environmental conservation are discussed by real conditions of the water resource utilities. The investigated area is the Xayar irrigated district in the Ugen River basin, one of branches of the Tarim River. The results confirmed by investigation are as follows: 1. The present conditions of irrigated agriculture have various contradictions and there are many points of improvement for conservation of the regional environment. 2. Water saving is necessary in the overall irrigation system for agricultural development. 3. Irrigated agriculture must be consolidated with the drainage system for the prevention of salinization and desertification.
\end{abstract}

Keywords: salinization, winter irrigation, arid area, Tarim River.

\section{Introduction}

The Tarim River, which flows south of the Tian Shan Mountains, is the longest inland waterway in China. Its main stream length is $1321 \mathrm{~km}$. The irrigated area in the Tarim Basin measures 1.6 million hectares. Cotton and fruits are produced in this area. Land reclamation has caused an increase in irrigation water intake from the Tarim River, which has caused the river's discharge to markedly decrease.

This decrease has caused ecological damage at the middle and lower reaches, particularly at the lower reaches. For example, 94\% of the Yingsu region, at the 
lower reaches of the Tarim River, has become desertified, and the Kumtag and Taklamakan deserts are starting to merge. This desertification has forced inhabitants to relocate, and abandoned villages dot the lower reaches of the basin. Some regions in the Tarim River basin began using large amounts of irrigation water in the 1960's, when large-scale development of irrigation channels was conducted, but there was no construction of proper drainage. The groundwater level of much agricultural land rose rapidly, and salt accumulation has occurred in about $80 \%$ of the irrigated area.

Agricultural use accounts for $90 \%$ of the water supply. Regional environmental conservation requires a reconsideration of agricultural water use. This paper examines the relationship between agricultural water management and the regional environment in an arid area by understanding agricultural water use in the Xayar Irrigation District of the Ugen River basin. (The Ugen River flows into the Tarim River at the middle reaches of that river.)

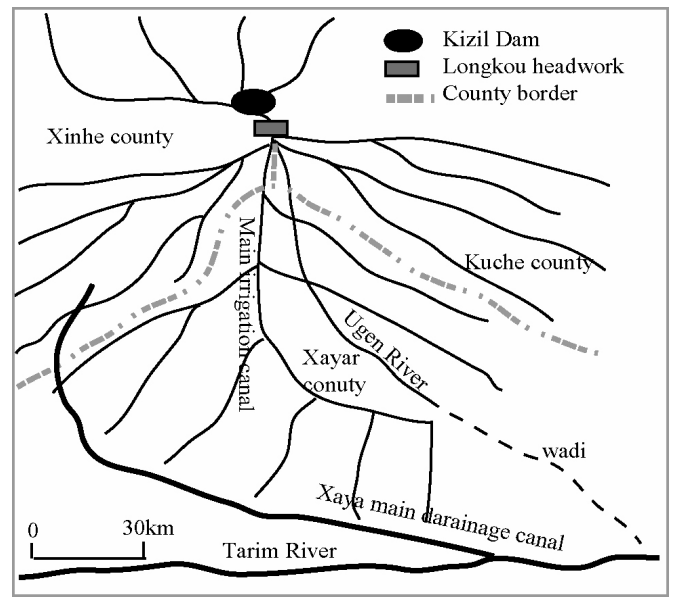

Figure 1: Outline of Ugen River basin.

\section{Study area and method}

\subsection{Study area}

The Ugen River is a branch on the Tarim River, and it flows from the Tian Shan Mountains. Kizil Dam was constructed where the mountains meet the plains. The Longkou headworks, downstream of this dam, distribute water for irrigation in the Ugen River Irrigation District. The district is in eastern Akesu Prefecture and borders the Tarim Basin to the south, the Tian Shan Mountains to the north, farmland of the Xinjiang Production and Construction Corps to the west, and Bugur County of Bayin'gholin Mongol Autonomous Prefecture to the east. The land slopes from northwest to southeast at a gradient of $1 / 400$ to $1 / 4000$. The climate classification of the irrigation district is arid $(\mathrm{BWk})$; the annual mean 
temperature is $11.4{ }^{\circ} \mathrm{C}$. The annual temperature range is great, with a maximum of $46.5{ }^{\circ} \mathrm{C}$ and a minimum of $-27.4{ }^{\circ} \mathrm{C}$. Annual rainfall is $67.3 \mathrm{~mm}$, and the potential evaporation is $2,131 \mathrm{~mm}$.

The Ugen River Irrigation District has three counties: Xayar, Kuche and Xinhe.

\subsection{Materials and methods}

The investigation area is the Xayar Irrigation District in the Ugen River basin. The district has 8 townships. The irrigation area has increased to 70,000 ha in 2003 from 20,000 in 1949. The main crops are wheat, corn, cotton and fruits. Table 1 breaks down the cultivated areas of these crops.

Most of the data on water use and management were provided by the Xayar Water Resource Agency. Field surveys and interviews with representative of the branch offices of the agency were conducted from 2003 to 2005.

Table 1: $\quad$ Crops and water supply demand [2].

\begin{tabular}{c|rrrrrrr|r}
\hline kinds & wheat & \multicolumn{1}{c}{ corn } & cotton & cauliflower & fruits & alfalfa & others & \multicolumn{1}{c}{ total } \\
\hline Nurbac township & 733.3 & 666.7 & 2060.0 & 33.3 & 703.3 & 600.0 & 320.0 & 5117 \\
Gurbac township & 1733.3 & 1333.3 & 5000.0 & 33.3 & 1116.7 & 563.3 & 310.0 & 10090 \\
Toibow town & 3333.3 & 3000.0 & 8066.7 & 133.3 & 1600.0 & 650.0 & 410.0 & 17193 \\
Honqi town & 2333.3 & 2000.0 & 2333.3 & 166.7 & 1366.7 & 700.0 & 260.0 & 9160 \\
Igimeri town & 2666.7 & 2666.7 & 4553.3 & 180.0 & 1350.0 & 210.0 & 305.0 & 11932 \\
Kairou town & 1933.3 & 1933.3 & 4955.3 & 113.3 & 1316.7 & 310.0 & 290.0 & 10852 \\
Xayar town & 133.3 & 66.7 & 280.0 & 6.7 & 146.7 & 100.0 & 276.0 & 1009 \\
New cultivated farm & 266.7 & 133.3 & 3186.7 & 0.0 & 200.0 & 200.0 & 129.0 & 4116 \\
\hline total (ha) & 13133.3 & 11800.0 & 30435.3 & 666.7 & 7800.0 & 3333.3 & 2300.0 & 69469 \\
\hline Planning irrigation & 540 & 390 & 540 & 465 & 435 & 345 & 480 & \\
water supply (mm) & & & & & & & & \\
Irrigation water & 71 & 46 & 164 & 3 & 34 & 12 & 11 & 341 \\
demand (million & 71 & & & & &
\end{tabular}

\section{Results}

\subsection{Water resources}

The average of annual discharge of the Ugen River is 2280 million $\mathrm{m}^{3} / \mathrm{y}$, and the average discharge is $72.3 \mathrm{ton} / \mathrm{s}$. The Ugen River takes its water from snowmelt and glacier melt of the Tian Shan Mountains. Much of the water in this river is meltwater from snow and glaciers, which means that the water discharge is greatest in summer. Figure 2 shows the average monthly discharge at the Kizil gauging station from 1954 to 1998. The discharge from June to September accounts for $60 \%$ of the annual discharge, and there is less discharge during spring. Spring discharge is so low that the water for sowing is limited. Kizil Dam, at the upper reaches of the Ugen River, reserves 644 million tons for water supply in the dry season. 


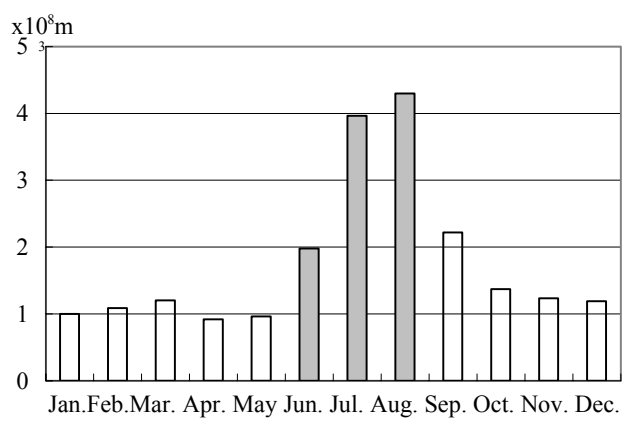

Figure 2: The average monthly discharge at Kizil water management office from 1954 to 1998 by using hydrological data of Xayar water management bureau [3].

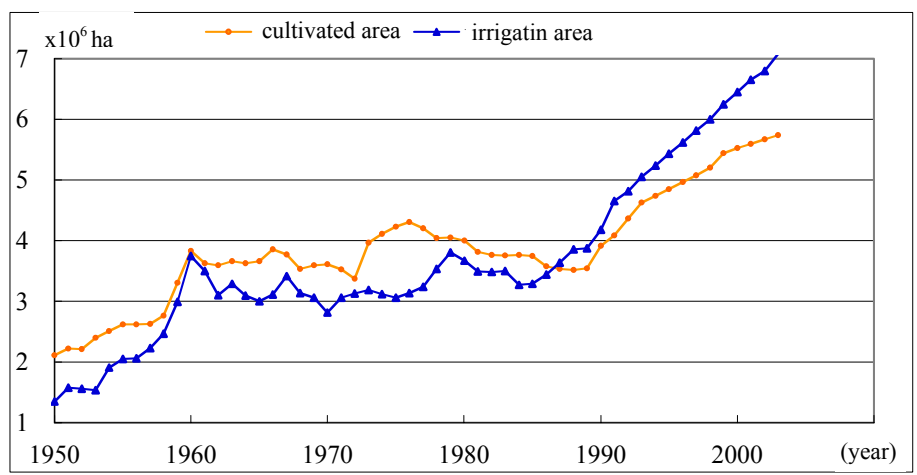

Figure 3: Change of cultivated area and irrigation area in Xayar by using hydrological data of Xinjiang water management bureau [4].

\subsection{Development in Xayar County}

Before 1949, cultivated land in Xayar county was generally owned by the landed gentry. The owner farmers practiced small-scale agriculture, and the tenant farmers practiced even smaller-scale agriculture. Large-scale irrigation facilities were not constructed by farmers because of their limited finances. Therefore, the cultivated area in Xayar did not expand much. Most farmers engaged in stock farming as a side job. From 1949, the Chinese social system changed completely and the People's Commune system of collectivized agriculture began. In the 50 years since then, the area of cultivated land has undergone dramatic increase three times, in line with social changes and their accompanying changes in agricultural policy.

In the 1950's, under the People's Commune and the Great Leap Forward, large areas of grassland were converted into cultivated land [4]. Much cultivated 
land was developed in the 1970's, during the Cultural Revolution. In the 1980's the introduction of price supports for cash crops (e.g., cotton) and a contract work system encouraged farmers to produce crops. Land reclamation accelerated. Double cropping increased the demand for water, which promoted the expansion of irrigation.

\subsection{Development of water resources}

Irrigation is the most important factor for agriculture in an arid area. Most of the irrigated land in Xayar county went through four states of irrigation:

\subsubsection{Irrigation using river water}

All cultivated fields in the alluvial fan were irrigated with Ugen River water. Often in the past, the agricultural water rights for each community were managed by a community or community alliances. In practice, the rights were exercised by landholders or middle-class farmers. In times of drought, conflicts arose over agricultural water and these sometimes developed into armed conflicts between communities.

\subsubsection{Irrigation using reservoir water}

Before 1949, agriculture in Xayar county depended on river water flow. The water resources were developed largely after the People's Commune was established [5]. Nineteen reservoirs for irrigation water in Xayar county were constructed between 1958 and 1970. These reservoirs can hold 80 million $\mathrm{m}^{3}$. Only two of these reservoirs were usable, because they were constructed by professional engineers. The 17 others were abandoned because of leakage or salinization of the surrounding farmland [4].

\subsubsection{Irrigation using well water}

Irrigation using well water: The socioeconomic changes resulted in increased water demand. Many farmers did not have enough irrigation water from rivers and reservoirs for their expanded farmland. By 1990, more than 1000 wells had been dug using state funds, but the costs of maintaining and operating those wells are too high, and the water quality is low. Farmers have not aggressively used well water.

\subsubsection{Irrigation from the multipurpose dam}

Twenty percent of the Ugen River's annual discharge is stored in Kizil Dam, a multipurpose dam constructed at the upper reaches of the river in 1991. As result of that construction, the irrigated area in Xayar county greatly expanded.

\subsection{Improvement of irrigation and drainage}

The irrigation water is supplied from the Longkou headworks to the Xayar Main Irrigation Canal (length: $50 \mathrm{~km}$ ). The water is delivered using a five-step canal irrigation system (Table 2).

The Xayar Main Irrigation Canal has 10 diversion gates. The design discharge is $60 \mathrm{~m}^{3} / \mathrm{s}$ at the uppermost gate and $30 \mathrm{~m}^{3} / \mathrm{s}$ at the lowermost gate. The irrigation 
area is 70 thousand ha. The outflow to the Xayar district is 740 million $\mathrm{m}^{3}$ per year, which accounts for $32.5 \%$ of the annual average discharge of the Ugen River. Four percent of the irrigation canal length is unlined. The water supply efficiency is only $40 \%$. Drainage canals have been dug since 1966, the decade when irrigation canal improvements were launched. The drainage canal system consists of three types of drainage canal: the Xayar Main Drainage Canal, three secondary canals, and nine tertiary canals. The Xayar Main Drainage Canal extends $84 \mathrm{~km}$, from northern Xayar to the Tarim River. However, the government and farmers have no incentive to develop farmland drainage. There are few ditches connected with tertiary drainage canals. The drainage system seems to be inadequate.

\subsection{Water management system}

Water distribution from the Longkou headwork was decided by agreement between three counties in the Ugen River Irrigation District. From those consultations, $32.5 \%$ of the water was been allotted to the Xayar Irrigation District. The Xayar Water Management Office manages this water and distributes it to its eight branch offices. Distribution is proportional to farmland area. Each branch office controls irrigation facilities, distributes irrigation water to farmland, confirms the irrigated area, records amount of irrigation water and collects water fees.

Table 2: $\quad$ Types of irrigation canal.

\begin{tabular}{cccccc}
\hline irrigation canal types & count & $\begin{array}{c}\text { discharge } \\
\left(\mathrm{m}^{3} / \mathrm{s}\right)\end{array}$ & $\begin{array}{c}\text { total canal length } \\
(\mathrm{km})\end{array}$ & $\begin{array}{c}\text { total lining canal } \\
\text { length } \\
(\mathrm{km})\end{array}$ & $\begin{array}{c}\text { ratio of } \\
\text { lininng }\end{array}$ \\
\hline main canal & 1 & $60<30$ & 50.5 & 33.5 & 66.3 \\
first branch canals & 25 & $1 \sim 7$ & 471.4 & 82.2 & 17.4 \\
second branch canals & 79 & $1 \sim 5$ & 589.6 & 31.2 & 5.3 \\
$\begin{array}{c}\text { third branch canals } \\
\text { farm ditches }\end{array}$ & 402 & $1 \leq$ & 1316.0 & 0.0 & 0 \\
\hline total & unknown & & 1142.0 & 0.0 & 0 \\
\hline
\end{tabular}

\subsection{Irrigation methods}

In the Xayar district, the water management offices supply irrigation water twice a year: once in the warm season (Apr. to Sep.), and once in the winter season (Nov. to Feb.). Warm-season irrigation aims at crop growth. The purpose of winter irrigation is to increase soil moisture content in the field even in the cold season.

Irrigation is by border method, whose efficiency is low. From late 1990's, wide levees were narrowed and long levees were shortened. The present standard lot size is $60 \mathrm{~m} \mathrm{x} 40 \mathrm{~m}$. But due to a lack of interest in water conservation, farmers often over-irrigate to the point of flooding their fields. 
The water supply efficiency is only $40 \%$, which means that only 296 million

$\mathrm{m}^{3}$ of irrigation water reaches farmlands. There is a $45-$ million- $\mathrm{m}^{3}$ shortage of irrigation water, because demand is 341 million $\mathrm{m}^{3}$ in this irrigation district. Cotton production per unit area in the district is nearly 30\% less than on farmland of the Xinjiang Production and Construction Corps, whose water supply meets the demand. This means lack of water is a barrier to growth. As a remedy, it is necessary to increase the efficiency of irrigation by improving irrigation methods, and to increase the water supply efficiency.

\section{Discussion: problems in irrigation and drainage systems}

\subsection{Irrigation and the regional environment}

Border irrigation was introduced to farmlands in the district. The groundwater level has risen due to poor drainage. Because the discharge of the Ugen River is low in the sowing period of early spring, a unique irrigation method (winter irrigation) has been introduced to keep supplying water in the post-harvest period. Drainage has not been systematically developed, even though the reclaimed land is at a low elevation. The construction of drainage canals did not start until salinization occurred. This is careless planning and management.

The area of land that underwent salinization expanded rapidly due to rises in groundwater level and the absence of a functional drainage system. Water waste seems to promote desertification. Many farmlands have been abandoned. For example, $10 \%$ of reclaimed farmland has been abandoned in Nurbac Township of Xayar County. Not only has such irrigation caused farmland salinization, it has also raised the salinity of the drainage water. This drainage water has adversely affected the environment of the Ugen and Tarim rivers.

\subsection{Problems of water management}

\subsubsection{Water management organization}

The Xayar District Water Management Office is under the control of the Xayar County government. The office's budget comes from general operating expenditures of the county government. The government's annual revenue increases with increases in the sale of water. But this means that government revenue decreases if conservation results in an unsaleable surplus of water. The management office has less incentive to conserve water, because the government guarantees its finances.

\subsubsection{Water fee}

Water fees vary from one area to another. Each irrigation block is managed by several farmers. The water fees are calculated by dividing the irrigation volume supplied to each irrigation block by the area of farmland owned by each farmer. A farmer cannot save on water fees by conservation unless all farmers in that block conserve water. As result, many farmers have no incentive to conserve water. 


\subsubsection{Political flaws in the development of water resources and in land reclamation}

Water resource development and land reclamation should be integrated. But the water management office, incomprehensibly, has no jurisdiction over land reclamation. Therefore, the expansion of farmland and tenant farmland has exceeded the water supply. Since the office supplies a fixed volume of water to each farmland, some farmers have suffered from water shortages.

\subsubsection{Farmer cooperation for water management}

Controlling the irrigation system requires cooperation between farmers. Cooperation in the maintenance of irrigation canals can foster in farmers a sense of community and responsible water management. In government-led, largescale irrigation, the water supply and distribution depend on the decisions of water management offices. Therefore, no sense of community is fostered in farmers.

\subsection{Sustainable irrigated agriculture}

The establishment of appropriate irrigation methods and a drainage method for control of the groundwater level are significant issues in preventing salinization. Some farmers understand the importance of water-saving irrigation. However, capital investment in water-saving irrigation by the farmers themselves seems difficult at this time. There are several water-saving irrigation systems that have been introduced using state funds; however, some have not been used efficiently by farmers due to their lack of skill and facilities. In the light of this, state funds must be supplemented by improvement of farmers' skills in water-saving irrigation. It is expected that development of farmland drainage and improvement of water supply efficiency will avoid groundwater lowering and water salinization. The winter flood irrigation that is unique to this area has the potential to accelerate groundwater salinization. Suitable irrigation methods need to be determined, including winter flood irrigation.

\section{Conclusion}

In arid areas where water resources are insufficient, water for expanded agricultural production - that is, expansion of the irrigated area - must be secured by water-saving irrigation. Toward this, the principles of agricultural water use must be understood by users and managers. Concretely, the principle means reducing water loss by ensuring appropriate control, building watersaving incentives into the water supply system, and reducing water waste by rational water management.

Additionally, it must be realized that developing and promoting farmlandlevel water-saving irrigation and educating farmers about it is necessary. Furthermore, it is necessary for regions where the main industry is irrigation agriculture to promote socioeconomic development and to comprehensively review and improve irrigation systems, water supply administrations, and a production structure that has various contradictions. 
Regional environmental conservation is only secured by maintaining sustainable irrigated agriculture in this region. Irrigation that does not exceed the Environmental Carrying Capacity must be sought.

\section{Acknowledgments}

Research was supported by Xayar county Government, Water management office and Xinjiang Uyghur Autonomous Region Water Management Bureau.

\section{References}

[1] Kuche county historiographic committee, Kuche county History, Xinjiang University publisher, pp.85-87, 1993.

[2] Xinjiang Xayar water management office, Hydrological data, internal consumption (inedited).

[3] Hydrologic Office in Xinjiang Water Management bureau, Hydrological data, internal consumption (inedited).

[4] Xinjiang Uyghur Autonomous Region Economic Leads the group and XinjiangUyghur Autonomous Region Statistic Office edited, Social Economic of Developing cities in Xinjiang, Xinjiang public publisher, pp.320-321, 1995.

[5] Xayar county historiographic committee, Xayar county History, Xinjiang public publisher, p.214, 1995. 